\title{
Interrelationships between Water, Food and Digestible Energy Intake in Desert and Temperate Goats
}

\author{
NISSIM SILANIKOVE \\ Department of Zoology, University of Tel Aviv
}

Intra- and interspecific relationships between energy intake and digestible energy intake (DEI) and water turnover (WTO) in Black Bedouin and temperate (Swiss Saanen) goats were analyzed. Available data from other species of mammals were also evaluated. A highly significant linear relationship between WTO and DEI holds within breeds of goats under different levels of DEI and between breeds which vary considerably in their body weight and metabolic expenditure (WTO $\mathrm{ml} / \mathrm{kg}$ per day $=-5.4+0.911 \mathrm{DEI} \mathrm{kcal} / \mathrm{kg}$ per day, $n=34, r^{2}=0.99, \mathrm{Sb}=0.057$ ). In lactating goats the relation between WTO rate (minus water secreted in milk) and DEI is the same as that measured in non-lactating ones. Mammals with quite a different body weight have the same WTO per unit of metabolism-about 1 mol of water per $5 \mathrm{~mol}$ of oxygen -although their absolute turnover is very different. Furthermore, the above relationship is similar to the relationship between WTO: DEI found in goats here. (WTO $\mathrm{ml} / \mathrm{kg}$ per day $=5 \cdot 8+0.849 \times \mathrm{kcal} / \mathrm{kg}$ per day, $n=8, r^{2}=0.99$, $\mathrm{Sb}=0.030$, where $x$ is the caloric equivalent of oxygen consumption.)

\section{INTRODUCTION}

There is a wealth of understanding about the physiological and neurological basis of drinking in response to challenges to fluid homeostasis (Fitzsimons, 1979). When water supply is unlimited in ruminants as well as in other mammals there is a close relationship between the amount of food consumed and the amount of water consumed, or water turnover rate (WTO) (Chew, 1965; Macfarlane \& Howard, 1972; Kraly, 1984). In addition, a close relationship in all genuses or species between the amount of WTO rate and oxygen used was found (Macfarlane \& Howard, 1972). It is obvious that each of the two relationships mentioned could be derived from the other; it is not clear however, which of them is more dominant.

It is well known that water and energy economies are much more frugal in desertadapted species and breeds in comparison to close relatives from more moderate climates (Chew, 1965; Macfarlane \& Howard, 1972). It is also well established (Macfarlane et al., 1971; Schmidt-Nielsen, 1964) that the lower energy requirement of desert species and breeds results from a lower metabolic rate. The lower metabolic rate of desert goats was related recently to lower mass proportion of their visceral organs (Silanikove, 1987). However, with regard to the lower water requirement of desert species and breeds it is not clear whether their water metabolism is systematically different or merely a reflection of their lower metabolic ratc.

This work has been carried out in the Environmental and Comparative Physiology Laboratory of Prof. A. Shkolnik al the Tel Aviv University. Professor Shkolnik's assistance in carrying out this study is greatly appreciated.

Present address: Agriculture Research Organisation, Zoo Technology Department, c/o Dr. E. Maltz. P.O. Box 6, Bet Dagan 50250, Israel. 
Considerable differences between food intake, digestible energy intake (DEI), digestion potential, kidney function, water intake and WTO rate were found between the desert Black Bedouin and non-desert goats (Shkolnik et al., 1972; Silanikove, 1984, 1985, 1986 a, b; Silanikove et al., 1980). The aim of the present experiment was to compare intra- and interspecific relations between energy intake or DEI and water intake, or WTO rate in Black Bedouin and temperate Swiss Saanen goats. By using a comparative physiological approach, two problems were examined to define more clearly causal relations between food and water economy in mammals:

(1) Are water intake and WTO independently regulated or linked to animal energy metabolism?

(2) Is drinking related to eating, independently regulated or does it derive from a more basic relationship?

\section{METHODS}

\section{Animals}

A small herd of Black Bedouin goats was purchased from Bedouins in the Eastern Sinai along the Gulf of Eilat. The herd was kept and bred in the research zoo of Tel Aviv University under continuous veterinary supervision. Experiments were conducted on four Black Bedouin and four Swiss Saanen goats. All animals were adult non-lactating females. The body mass of the goats used in this study ranged from $18-22 \mathrm{~kg}$ (Bedouin) to $30-50 \mathrm{~kg}$ (Swiss).

\section{Diets}

High (alfalfa hay) and low (wheat straw) quality diets were tested. The grading of the diets was based on composition of nitrogen and cell wall constituents (Silanikove, $1986 \mathrm{a}$ ). The alfalfa hay diet was also tested under restriction of intake to $65 \%$ ad libitum consumption. The energy content ( $4.4 \mathrm{kcal} / \mathrm{g} \mathrm{d}$.m.) and dry matter (d.m.) content $(90 \%)$ of both diets was about the same.

Intake was expressed, therefore, as gross caloric intake. This allows comparison on the same basis with data on DEI or energy metabolism.

\section{Experimental procedures}

Goats from both breeds were kept simultaneously in metabolic cages at room temperatures ranging from $22-26^{\circ} \mathrm{C}$ and relative humidity of $60-70 \%$. Temperature fluctuations within each experiment were $\pm 2^{\circ} \mathrm{C}$. Thirty days were given for adaptation of each diet. Food in baled form in an amount $10 \%$ above the intake recorded on the previous day was given in two cqual portions at 0700 and $1600 \mathrm{hrs}$. Food residues and fecal output were recorded daily for 10 days. Daily subsamples $(5 \%)$ of food residues and fecal output were pooled for chemical analysis. Apparent gross energy digestibility was calculated according to the total collection method (Silanikove, 1986a). Water turnover rates were calculated from the rate of disappearance of tritiated water (Maltz et al., 1982). 


\section{RESULTS}

The components of water input are presented in Table 1. Performed water contributed about $4 \%$ of the WTO on the alfalfa hay diets and $4.8 \%$ (Bedouin) and $7.7 \%$ (Saanen) of the wheat straw diet. Metabolic water contributed approximately $30 \%$ of the WTO on the alfalfa hay diets and approximately $20 \%$ of wheat straw. Voluntary consumption of water was the main component of water input, amounting to $66 \%$ of the total water input on the alfalfa hay diets and $75 \%$ (Bedouin) and $70 \%$ (Saanen) on wheat straw. As the two first variables are respectively quantitatively and stoichiometrically related to food intake, it is obvious that the regulation of free water consumption was the main regulated variable which has been used to maintain the homeostasis of body fluid properly. It was established in parallel measurements that the goats were in steady state in terms of their water content (data not shown) and that their blood osmolality was at normal range, $295 \mathrm{mosmol} / \mathrm{kg}$ (Silanikove, $1986 \mathrm{~b}$ ) when they voluntarily consumed their water.

When the intake of alfalfa hay was reduced to about $65 \%$ of the ad libitum, all the variables included in Table 2 were reduced in direct proportion to the imposed reduction.

Food intake as gross energy ranged between $51 \mathrm{kcal} / \mathrm{kg}$ per day on wheat straw to $194 \mathrm{kcal} / \mathrm{kg}$ per day (range of $380 \%$ ) on alfalfa hay, while in Bedouin goats it ranged from $63 \mathrm{kcal} / \mathrm{kg}$ per day to $151 \mathrm{kcal} / \mathrm{kg}$ per day (range of $240 \%$ ) (Table 1). The corresponding values of water intake and WTO rates ranged between 12.7 and $18.2 \mathrm{ml} / \mathrm{kg}$ per day on wheat straw to 74.6 and $114.1 \mathrm{ml} / \mathrm{kg}$ per day (range of 587 and $627 \%$ ) on alfalfa hay in the Saanens and from 27 to $37.8 \mathrm{mi} / \mathrm{kg}$ per day to 53.5 and $84.1 \mathrm{ml} / \mathrm{kg}$ per day (range of 192 and $224 \%$ ) in the Bedouin goats (Table 1). A significant linear relationship exists between energy intake and water intake or WTO rates in goats with the same slope for both breeds of goats (Table 2).

Nevertheless, specific $t$-test analysis indicates that the ratio between water intake and food as gross energy intake (GEI) in Saanen goats fed wheat straw $(0.249 \pm 0.031)$ was significantly $(p<0.05)$ lower than on alfalfa-based diets $(0.385 \pm 0.036$ ad libitum; $0.395 \pm 0 \cdot 035,65 \%$ restricted). No such drop in the ratio between water intake and GEI was recorded with the Bedouin goats $(0.442 \pm 0.061$ wheat straw, $0.354 \pm 0.055$ alfalfa hay ad libitum; $0.405 \pm 0.035$ alfalfa hay reduced to $65 \%$ of the ad libitum).

Differences between the two breeds of goats in the digestive capacity, energy requirements and fluctuations in body weight, as described in detail previously (Silanikove, 1985, 1986 a, b; Silanikove et al., 1980), were reflected in wider differences in DEI. Digestible energy intake ranged between $20.3 \mathrm{kcal} / \mathrm{kg}$ per day on wheat straw to $132 \mathrm{kcal} / \mathrm{kg}$ per day (range of $650 \%$ ) of alfalfa hay in the Saanens, while in the Bedouin goats it ranged between $32 \mathrm{kcal} / \mathrm{kg}$ per day and $109 \mathrm{kcal} / \mathrm{kg}$ per day $(330 \%)$. Moreover, the correlation of the relationship between DEI and WTO is significantly higher than in the relationship between energy intake and water intake or WTO rates $\left(r^{2}=0.99\right.$ vs. $r^{2}=0.55$ and $r^{2}=0.65$ ) and the scattering of the results along the regression line is less $\left(S_{b}=5.7 \%\right.$ vs. $S_{b}=35 \%$ and $S_{b}=15 \%$ ) (Table 2$)$. The described differences in the relationships between DEI and energy intake with WTO were found by both intra- and interbreed comparisons. In the three relationships (Table 2) the intercept of the regression lines is not statistically different from zero. 

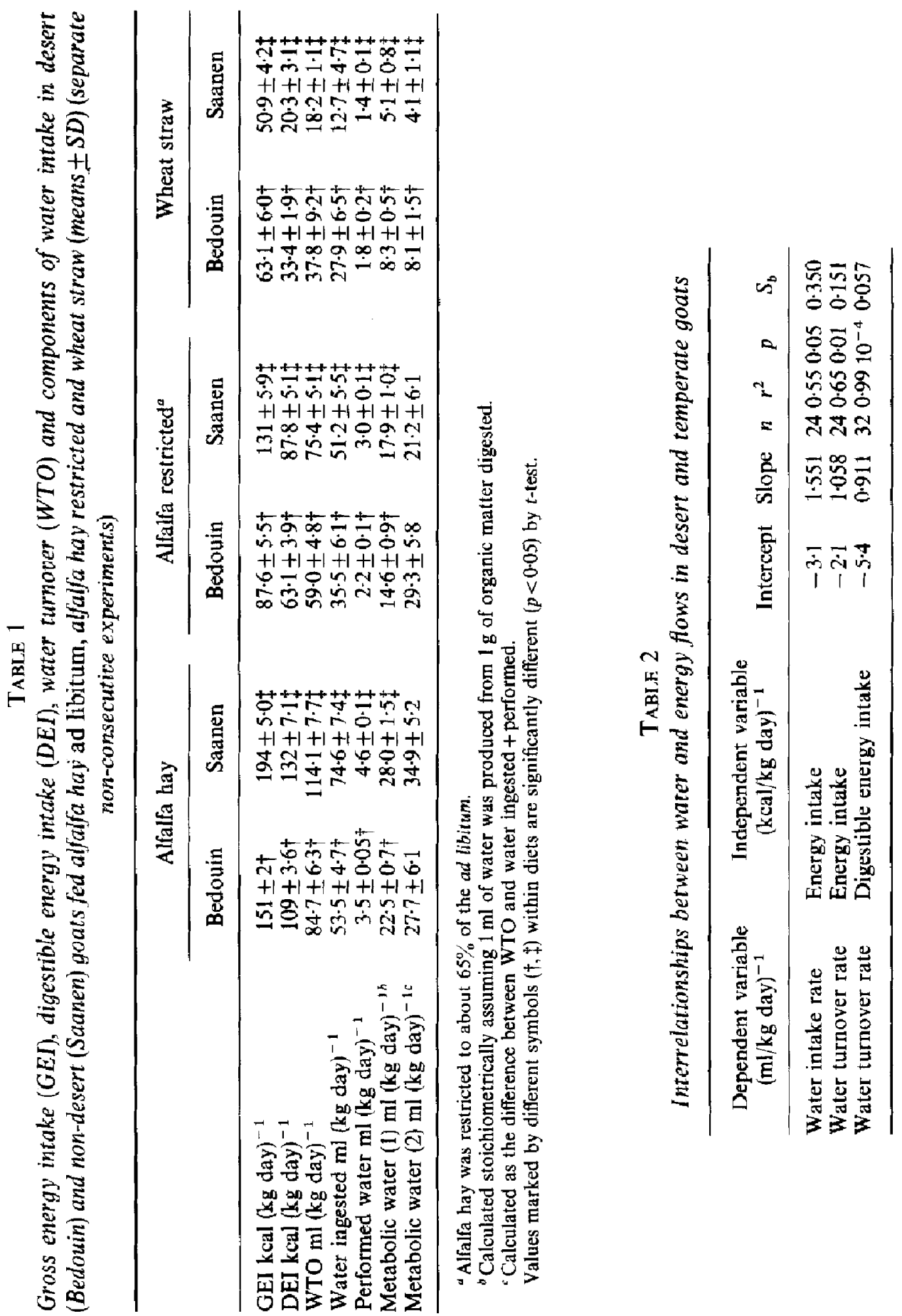


\section{DisCUSSION}

This research adds more information to the long established observations that energy and water exchanges are closely related in mammals.

Many earlier studies have shown that WTO rates in desert adapted species is lower than in close relatives from more moderate climates (Chew, 1965; Kennedy \& Macfarlane, 1971; Macfarlane \& Howard, 1972; Macfarlane et al., 1971; Yosef et al., 1974). This work provides evidence indicating that the lower WTO in desert animals should be carefully analyzed. If WTO rate is related to DEI, there is no systematic difference between the highly desert adapted Bedouin goats and domestic goats from moderate climates (Saanens). For example, the higher WTO rates in Bedouin, as compared to Saanen goats, when fed low quality feed (wheat straw), reflects the proportionally higher DEI in the Bedouin goat.

The result of the present work does not support the current belief (Macfarlane \& Howard, 1972) that desert-adapted species possess special mechanisms for reducing WTO rates in the absence of heat or osmotic stress. It is well known that many desert animals have lower metabolic rates than relatives from moderate climates; their lower WTO rates now seems in most cases to be merely a consequence of their lower metabolic rates. The reservation for the absence of heat and osmotic effectsnoted above should include high protein diets. Fitzsimons \& Le Magnen (1969) found that the water-to-food intake ratio is much higher on protein-rich diets than on a carbohydraterich ones. This difference is commonly attributed to the larger osmotic load and requirement of urinary output due to large protein catabolism in protein-rich diets. However, some desert mammals have outstanding capability to concentrate their urine with urea, thereby effectively preserving their urinary output even when fed a proteinrich diet (Schmidt-Nielsen, 1964).

Water turnover rates in lactating mammals is higher than in non-lactating ones, even after accounting for the amount of water secreted in milk from WTO rates. This probably reflects the response to an increase of energy metabolism during lactation (Maltz et al., 1982; Macfarlane et al., 1969; Macfarlane \& Howard, 1972). From data on lactating Bedouin goats and lactating goats from temperate areas (Figure 1), it seems that the WTO:DEI ratio remains constant during periods where water and energy metabolism are accelerated in response to productive demands, like milk production.

From separate measurements of oxygen consumption and WTO rate in different genuses and species of mammals it is well established that these two variables are closely related to each other (Macfarlane \& Howard, 1972). Limited available published results in which oxygen consumption and WTO were measured under the same experimental conditions are summarized in Table 3 . From Table 3 it seems that mammals of quite a different body weight have the same WTO per unit of metabolism, although their absolute turnovers were very different. Furthermore, the relation between WTO:metabolism recorded in those mammals is very close to the relation between WTO: DEI found in goats in the present work. The same relationship was also found between WTO rates and DEI in some non-ruminant species (Figure 1).

Drinking elicited by eating (Kraly, 1984) seems to be, according to this research, a derivation of a more basic relationship the proportional exchange of water and energy. This conclusion is based on the considerably higher correlation and lower variability of the WTO:DEI interrelationship compared with the food (GEI): water interrelationship. Changes in food intake may account for a large proportion in changes of metabolism (Silanikove, 1987) and similarly, changes in water intake may 


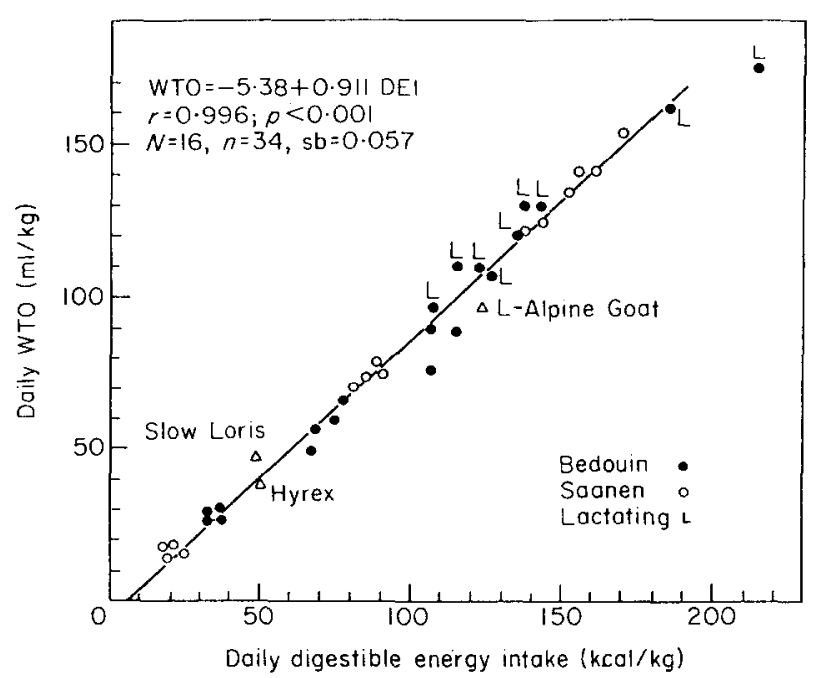

FIGURE 1. Interrelationships between digestible energy intake and water turnover (WTO) rate in Bedouin (O) and Saanen $(O)$ goats. (In lactating animals $(L)$ the amount of water secreted in the milk was subtracted from the water turnover rate.) Data from other animals are added for comparison.

Sources: lactating Bedouin goats, Maltz et al. (1982) (data on the lactating Bedouin goat was included in the regression analysis); lactating Alpine goats, Giger et al. (1981); slow loris, Muller (1979); hyrax (Procavia capensis Syriaca Schreber 1784), Ferrel, N. \& Silanikove, N. (unpublished results).

account for large proportion in changes of water metabolism (Table 1). However, it is obvious that DEI and WTO are better related (Table 2), indicating that food: water interrelationship are secondly derived from more basic dependency.

In the light of inadequacies of physiological thirst model (Fitzsimons, 1979) to account for drinking in non-stressed animals, behavioral models have been forwarded (Toates, 1979). However, as shown in Figure 1 and Table 3, mammals with extreme diversity in their feeding and drinking behavior have the same proportionality of energy and water exchange. This can be obtained only if similar homeostatic physiological mechanisms are controlling the proportional exchange of water and energy (that includes the drinking related to eating phenomena) operating in all of them.

The potential physiological mechanisms underlying food-related drinking were recently reviewed by Kraly $(1984,1985)$. Both the preabsorbative and postabsorbative vagal depended mechanisms were implicated. On the basis of the interpretation of the present results, it seems that control of water intake by postabsorbative effects of digested food should be the determining factor. However, Fitzsimons \& Le Magnen (1969) have shown that in rats, eating stimulated drinking and that the amount of dry food eaten positively related to the followed water intake. Accordingly, preabsorbative effects of food are probably important in "approximate tuning" of adapted water intake by providing signals allowing to anticipate the amount of water that will be needed to maintain homeostasis.

As in the case of energy metabolism, there is a logarithmic linear relationship between WTO and body mass among mammals (Richmond et al., 1962; Macfarlane \& Howard, 1972). However, the exponents which were found to best describe the relation between WTO and body mass $(0.80$ and 0.82$)$ are different from the exponent $(0.75)$ 
TABLE 3

Water turnover (WTO) and oxygen consumption of different mammals ${ }^{a b c}$

\begin{tabular}{|c|c|c|c|c|}
\hline Species & $\begin{array}{l}\text { Body } \\
\text { mass } \\
(\mathrm{kg})\end{array}$ & $\begin{array}{c}\text { Oxygen } \\
\text { consumption } \\
1 \mathrm{O}_{2}(\mathrm{~kg} \text { day })^{-1}\end{array}$ & $\begin{array}{c}\text { Water turnover } \\
\mathrm{ml}_{2} \mathrm{O}\left(\mathrm{kg} \mathrm{day}^{-1}\right.\end{array}$ & $\begin{array}{l}\text { Water turnover } \\
\text { per caloric } \\
\text { equivalent (in } \\
\text { kcal) of oxygen } \\
\text { consumption }\end{array}$ \\
\hline Slughi (dog) & 20 & $7 \cdot 8$ & $31 \cdot 1$ & 0.83 \\
\hline Canaan (dog) & $18 \cdot 2$ & $7 \cdot 3$ & $31 \cdot 1$ & 0.89 \\
\hline Pointer (dog) & 26.8 & $8 \cdot 5$ & $50 \cdot 5$ & 1.24 \\
\hline Elephant shrew & 0.05 & $26 \cdot 2$ & 140 & $1 \cdot 11$ \\
\hline $\begin{array}{l}\text { Dasycercus } \\
\text { cristicauda } \\
\text { Sminthonshsis }\end{array}$ & 0.086 & $35 \cdot 8$ & 134 & 0.78 \\
\hline crassicaudata & $0 \cdot 113$ & $112 \cdot 1$ & 462 & 0.86 \\
\hline Slow loris & $0.76-2 \cdot 0$ & $7 \cdot 0$ & $37 \cdot 7$ & 0.89 \\
\hline Rock hyrax & $2 \cdot 5$ & 6.9 & $37 \cdot 3$ & 0.89 \\
\hline
\end{tabular}

${ }^{a}$ The measurements in each species were taken at the same experimental conditions at thermoneutral ambicnt temperatures with animals at rest.

${ }^{b}$ The ratio between WTO and caloric equivalent of oxygen consumption was calculated assuming: $4.8 \mathrm{kcal}$ per litre oxygen. Linear regression analysis results: WTO ml $(\mathrm{kg} \mathrm{day})^{-1}=5.8+0.849 \times \mathrm{kcal}(\mathrm{kg} \text { day })^{-1}$, $r^{2}=0.99, p<0.001, s_{b}=0.030$, where $x$ is the caloric equivalent of oxygen consumption.

' References: Dog-Meir \& Shkolnik (1981). Shrew-Leen et al. (1983). Dasycercus cristicauda and Sminthopsis crassicaudata-Kennedy \& Macfarlane (1971). Slow loris-Muller (1979). Rock hyraxRubsamen et al. (1979).

commonly used to describe the energy : mass relations (Kleiber, 1961). These different exponents imply that body mass would influence the water:energy relations in mammals.

However, no such trends were noted in Figure 1 and Table 3 under wide mass differences (2.5 logarithmic scale). Data of the present experiment and the data gathered in Table 3 indicates that WTO:mass relationship is related secondarily to water:energy relationships. Since, in addition, there are no statistical differences between the $0.80( \pm 0.09)$ (water : mass relation, Richmond et al., 1962) and 0.75( \pm 0.05$)$ (energy : mass relation, Kleiber, 1961) exponents, it is suggested that the 0.75 exponent should be used also for comparisons of the water : mass relationship between different mammals.

It may be concluded that the intra- and interspecific constancy of the relationship between WTO and DEI has a sound physiological basis which originates from intraand interspecific similarities of the interrelationships between WTO and energy metabolism in mammals.

It seems that measurements of WTO rate in feeding trials, carried out in thermoneutral conditions with dry feeds that do not contain excess salts or protein, may provide accurate information on DEI and the metabolic expenditure of the animals (Tables 2, 3). At this state, it may be especially applicable in trials with lactating and non-lactating goats when no alternative method to measure those parameters is available.

\section{REFERENCE Note}

1. Ferrel, N. \& Silanikove, N. (1986) Unpublished manuscript. Water metabolism in the desert hyrax (Procavia capensis). 


\section{REFERENCES}

Chew, R. M. (1965) Water physiology of mammals. In W. Mayer \& R. G. Van Gelder (Eds.) Physiological mammalogy (Vol. II), Academic Press.

Fitzsimons, J. T. (1979) The physiology of thirst and sodium appetite. New York: Cambridge University Press.

Fitzsimons, T. J. \& Le Magnen, J. (1969) Eating as a regulatory control of drinking in the rat. Journal of Comparative and Physiological Psychology, 67, 273-283.

Giger, S., Hervile, J., Sauvant, D. \& Morand-Fehr, P. (1981) Factors influencing and models to predict the water intake in lactating goats in temperatc climatc. In P. Morand-Fehr, A. Bourbouse \& Me de Simiare (Eds.) Nutrition and systems of goat feeding (Vol. I). Pp. 254-262. Tours: TOVIC-INRA.

Kennedy, P. M. \& Macfarlane, W. V.(1971) Oxygen consumption and water turnover of the battailed marsupials Dasycercus cristicauda and Sminthopsis crassicaudata. Comparative Biochemistry and Physiology, 40A, 723-732.

Kleiber, M. (1961) The fire of life. An introduction to animal energetics. New York: Wiley.

Kraly, F. S. (1984) Physiology of drinking elicited by drinking. Psychology Review, 4, 478-490.

Kraly, F. S. (1985) Histamine: A role in normal drinking. Appetite, 6, 153-158.

Leon, B., Shkolnik, A. \& Shkolnik, T. (1983) Temperature regulation and water metabolism in the elephant shrew Elephentulus edwards. Comparative Biochemistry and Physiology, 74A, 395-407.

Macfarlane, W. V. \& Howard, B. (1972) Comparative water and energy economy of wild and domestic mammals. Symposia of the Zoological Society of London, 31, 261-296.

Macfarlane, W. V., Howard, B. \& Siebert, B. D.(1969) Tritiated water in the measurement of milk intake and tissue growth of ruminants in the field. Nature (London), 221, 578-579.

Macfarlane, W. V., Howard, H., Haines, P., Kennedy, J. \& Sharpe, C. M. (1971) Hierarchy of water and energy turnover of desert mammals. Nature (London), 234, 483-484.

Maltz, E., Silanikove, N. \& Shkolnik, A. (1982) Energy cost and water requirement of Black Bedouin goats at different levels of production. Journal of Agricultural Science, Cambridge, 98, 499-504.

Meir, M. \& Shkolnik, A. (1981) Water economy and thermoregulation of Slughi, Canaan and Pointer dogs. Israel Journal of Ecology, 30, 97.

Muller, E. F. (1979) Energy metabolism, thermoregulation and water budget in the slow loris (Nycticebus coucana, Boddaest 1785). Comparative Biochemistry and Physiology, 64A, $109-119$.

Richmond, C. R., Langham, W. H. \& Trujillo, T. T. (1962) Comparative metabolism of tritiated water by mammals. Journal of Cellular Comparative Physiology, 59, 45-53.

Rübsamen, K., Heller, R., Lawrenz, H. \& Engelhardt, W. V. (1979) Water and energy metabolism in the rock hyrax (Prucavia rabessincia). Journal of Comparative Physiology, B131, 303-309.

Schmidt-Nielsen, K. (1964) Desert animals: physiological problems of heat and water. Oxford: Clarendon Press.

Shkolnik, A., Borut, A. \& Chosniak, I. (1972) Water economy in the Bedouin goat. Symposia of the Zoological Society of London, 31, 229-242.

Silanikove, N. (1984) Renal excretion of urea in response to changes in nitrogen intake in desert (Black Bedouin) and non-desert (Swiss Saanen) goats. Comparative Biochemistry and Physiology, 79A, 651-654.

Silanikove, N. (1985) Effect of dehydration on feed intake and dry matter digestibility in desert (Black Bedouin) and non-desert (Swiss Saanen) goats fed on lucerne hay. Comparative Biochemistry and Physiology, 80A, 449-452.

Silanikove, N. (1986 a) Interrelationships between feed quality, digestibility, feed consumption and energy requirements in desert (Bedouin) and temperate (Saanen) goats. Journal of Dairy Science, 69, 2157-2162.

Silanikove, N. (1986 b) Feed utilization, energy and nitrogen balance in the desert Black Bedouin goat. World Review of Animal Production, 22, 93-96.

Silanikove, N. (1987) Effect of imposed reduction in energy intake on resting and fasting heat production in the Black Bedouin goat. Nutrition Reports International, 35, 725-731.

Silanikove, N., Shkolnik, A. \& Tagari, H. (1980) Gross energy digestion and urea recycling in the desert Black Bedouin goat. Comparative Biochemistry and Physiology, 67 A, 215218.

Toates, F. M. (1979) Homeostasis and drinking. Behavioral and Brain Sciences, 2, 95-102.

Yosef, M. K., Johnson, H. D., Bradley, W. G. \& Seif, S. M. (1974) Tritiated water turnover rate in rodents: desert and mountain. Physiological Zoology, 47, 153-162. 